\title{
Lytic bacteriophages in Veterinary Medicine: a therapeutic option against bacterial pathogens?
}

\author{
Bacteriófagos líticos en Medicina Veterinaria: ¿una opción terapéutica frente a \\ patógenos bacterianos?
}

\author{
C Borie ${ }^{\mathrm{a}}$, J Robeson ${ }^{\mathrm{b}}$, N Galarce ${ }^{\mathrm{a}}$ \\ ${ }^{a}$ Laboratorio de Bacteriología, Facultad de Ciencias Veterinarias y Pecuarias, Universidad de Chile, Santiago, Chile. \\ 'Laboratorio de Bacteriología, Instituto de Biología, Pontificia Universidad Católica de Valparaíso, Valparaíso, Chile.
}

\begin{abstract}
RESUMEN
La elevada prevalencia de ciertas infecciones en los animales y su impacto económico a nivel productivo y en salud pública, han orientado los esfuerzos hacia la búsqueda de nuevos métodos de control y prevención, alternativos o complementarios, que logren mitigar sus efectos nocivos. Este escenario se ha complicado más aún con la aparición, permanente y ascendente, de bacterias patógenas multi resistentes a diversos antimicrobianos, que han limitado las posibilidades de control. En la continua búsqueda de nuevos elementos terapéuticos, ha renacido el interés por estudiar la aplicación de bacteriófagos, virus que matan bacterias, como potenciales agentes antimicrobianos. En medicina veterinaria desde hace poco más de tres décadas que se analiza la fagoterapia en animales de producción, de compañía y experimentales como modelos de infección humana, siendo sus resultados alentadores en términos de disminuir la mortalidad, la severidad del cuadro clínico y el recuento bacteriano a nivel tisular. Estos beneficios se han logrado gracias al mayor conocimiento de la biología de los fagos, la avanzada tecnología que ha permitido mejorar la purificación de este tipo de virus y a sus ventajas inherentes como su inocuidad para los animales y para el ser humano. Actualmente, la investigación continúa abriendo sus horizontes hacia la industria alimentaria, considerando la aplicación de fagos en las etapas desde la "granja a la mesa", existiendo promisorios resultados al usarlo como una intervención en animales a su entrada a la planta de procesamiento.
\end{abstract}

Palabras clave: fagoterapia, bacteriófagos, enfermedades transmitidas por alimentos.

\section{SUMMARY}

The high prevalence of certain bacterial diseases in animals and their economic impact at the productive and public health levels, have directed attention towards the search for new methods of control and prevention, alternative or complementary, that aim to mitigate their adverse effects. This scenario is further complicated by the permanent and rising presence of pathogenic bacteria that are resistant to many antibiotics, limiting the choice of control strategies. In the continuous search for new therapies, there is a renewed interest on the application of bacteriophages, viruses that kill bacteria, as potential antimicrobial agents. Phage therapy in animal production, pets and experimental models of human infection have been discussed in veterinary medicine for 3 decades, with encouraging results in terms of reducing mortality, the severity of the clinical state and bacterial counts at tissue level. These benefits have been achieved thanks to increased knowledge of the biology of phages, better technology that allows their purification and their inherent advantages in terms of their safety for animals. Currently, phage research continues to open new horizons for both the medical industry and the food industry, considering the use of phages in the stages of "farm to fork", with promising results if used as an intervention in animals since their arrival to the slaughter house.

Key words: phage therapy, bacteriophages, bacterial food-borne pathogens.

\section{INTRODUCTION}

The search for an appropriate mechanism for the control of several bacterial pathogens of veterinary medical importance, especially those involving an impact on human and animal populations has been the subject of many investigations (CDC 1998). Bacterial diseases in domestic animals can cause detrimental effects generating direct

Accepted: 14.11.2013.

\# Fondecyt 1110038

*_cborie@uchile.cl. and indirect economic losses in production systems and, in the case of pets, involves affective cost which is difficult to quantify. Furthermore, there are bacterial pathogens that cause food-borne diseases with high public health impact (Newell et al 2010).

Since the discovery of penicillin by Alexander Fleming in 1928 and sulfas by Gerhard Domagk in 1932, numerous drugs with antimicrobial effects have been produced and used as therapy for the treatment of bacterial infections, with great success in controlling these pathogens. Their use has reduced the impact of disease in both people and different animal populations, and there is a wide range of 
substances being available with different mechanisms of action and therapeutic indications. Since their discovery, antimicrobials have been the first line of action against bacterial diseases. However, several years ago the presence and increase of bacterial resistance to many antimicrobials has been observed, becoming a subject of global concern in human and veterinary medicine, which has stimulated the introduction of new drugs (WHO 2000). Despite the speed at which new antimicrobial agents are being introduced into the market, bacteria have shown a remarkable and rapid ability to evolve multiresistance to these drugs. Currently, the emergence of antimicrobial resistant pathogens has led to an interest in discovering new therapeutic tools that allow replacing or complementing antimicrobials when combating bacterial diseases, particularly those associated with food-borne diseases.

Among these therapeutic tools are the bacteriophages, viruses described as biological agents that lyse bacteria, used before the advent of antibiotics and currently attracting the interest of the international scientific community (Boerlin 2010, Maura and Debarbieux 2011).

In this context, the research on the use of bacteriophages as a bacterial control method in veterinary medicine has become increasingly important, due to its promising results regarding the use of bacteriophages as therapeutic and prophylactic agents in animals, as biocontrol agents in contaminated foods, biopreservatives in processed foods and as biosanitizers in industrial equipment. The aim of this review is to describe the use of bacteriophages over time, their comparative advantages and disadvantages, and specifically their application as a therapeutic tool in several animal species.

\section{GENERAL CHARACTERISTICS OF BACTERIOPHAGES}

Bacteriophages (or phages) are viruses that infect only prokaryotes (bacteria and archaea) and produce their lysis, being this activity the cornerstone supporting the idea of using them as therapeutic agents (Skurnik and Strauch 2006, Ceyssens and Lavigne 2010). The discovery of phages has been the subject of various controversies to decide which researcher discovered them first. In 1896 the German bacteriologist Ernest Hankin, suggested that an unidentified substance in the water of rivers in India was responsible for antimicrobial activity that prevented the spread of a bacterium (currently Vibrio cholerae). Two years later, Gamaleya, a Russian bacteriologist, observed a similar phenomenon while working with Bacillus subtilis. It is currently accepted that they were described in 1915 by Frederick Twort and Felix d'Herelle in 1917 (Summers 2001), the latter being the first to use bacteriophages for therapeutic purposes (Sulakvelidze et al 2001).

Bacteriophages are highly ubiquitous, occupying all those world ecosystems where bacteria develop successfully, and may be isolated from surface and deep water ecosystems, soils, oral cavity and blood and guts of healthy humans and animals (Sulakvelidze et al 2001). They have been isolated from aquatic systems in quantities ranging from $10^{4}$ plaque forming units (PFU) to more than $10^{8} \mathrm{PFU} / \mathrm{mL}$, in fresh water sediments in ranges of $0.65 \mathrm{PFU}$ to $3 \times 10^{9} \mathrm{PFU} / \mathrm{g}$, and in marine environments in quantities over $12 \times 10^{9} \mathrm{PFU} / \mathrm{mL}$. In soils, concentrations of 0.7 to $2.7 \times 10^{8} \mathrm{PFU} / \mathrm{g}$ have been found (Gorski and Weber-Dabrowska 2004). Some bacteriophages are highly specific attacking only certain bacterial strains, while others are quite broad in their host range (Skurnik and Strauch 2006).

The taxonomy of these viruses is based on morphological and molecular characteristics. At least 4950 phages (96\%) have tails, constituting the Order Caudovirales, and the three families Siphoviridae, Podoviridae and Myoviridae. Polyhedral, filamentous and pleomorphic phages represent less than $4 \%$ of these viruses (Dabrowska et al 2005). Nucleic acids present in these viruses can be DNA or RNA, single or double stranded with most phages containing double stranded DNA (Skurnik and Strauch 2006).

Phages transfer their genome from one susceptible bacterium to another, wherein they direct the production of viral progeny. A specific group of bacteria is host to each phage: this group is often only one bacterial species, but several related species can sometimes be infected with the same phage. The phage infection cycle follows a number of programmed steps, where efficiency and coordination depend strongly on the metabolic state of the host cell (Ceyssens and Lavigne 2010). Regarding the molecular mechanisms of the infection of their hosts, bacteriophages can follow two different destinations. The so called "lytic or virulent bacteriophages" follow the lytic infection cycle, wherein the phage genome is injected into the bacteria and multiplies in the bacterial cell altering its metabolism, resulting in the lysis at the end of the cycle due to the action of a viral lysozyme, which allows the release of the viral progeny formed. This phenomenon, which occurs within minutes or hours, shows that the viral particles are autoreplicative entities at least as long as a bacterial population in sufficient numbers to support this event exists. Their lytic mechanism from an ecological viewpoint constitutes a predator/prey system, and from an epidemiological viewpoint a host-parasite model (Gorski and Weber-Dabrowska 2004). The phenomenon of transduction (transfer of bacterial DNA via phage) is rare in lytic phages (Monk et al 2010).

On the other side, the "lysogenic or tempered bacteriophages" use the lysogenic pathway, where the phage genome, after being injected in the bacterial cytoplasm, is integrated (prophage) and replicates as part of the host genome, remaining latent for extended periods; if the host bacterium faces adverse environmental conditions this prophage may activate and return to the lytic cycle, and later the newly formed phage particles are released after bacterial lysis (Skurnik and Strauch 2006). The integration of the viral genome into the bacterium's is the 
reason why they are not used in phage therapy since they could incorporate, carry and transfer genes coding for undesirable elements such as the Shiga toxin from Escherichia coli (Skurnik and Strauch 2006, Monk et al 2010).

The infectious cycle of a lytic bacteriophage comprises the following steps (Strauch Skurnik and 2006, Lavigne Ceyssens 2010):

- Bacteriophage adsorption to the bacterial cell through recognising specific bacterial cell structures by means of their fibers or tail spicules. For this purpose, the phage may use bacterial capsules, different parts of the LPS, flagella, fimbriae and some other surface proteins, oligosaccharides and lipopolysaccharides.

- Injection of the phage genome into the host bacterium: this is facilitated by an enzyme present in the phage tail tip which degrades the peptidoglycan. This introduction of the viral genome is energy-dependent, obtained from available ATP or the membrane potential of the bacterium (Letellier et al 2004).

- Early phage gene expression and synthesis of early proteins, involved in the intervention of the bacterial enzyme systems and viral genome replication.

- Phage genome replication.

- Expression of late phage proteins, involved in the formation of new viral particles, viral capsid formation and the lysis of the host bacteria.

- Assembly of phage heads and tails, and viral genome compaction.

- Lysis of the host bacteria and release of new phage progeny. This lysis is produced by the action of two enzymes which degrade the cell wall and the inner membrane, an endolysin and holin, respectively. Their action makes the cell lyse due to the structural inability to resist internal osmotic pressure. This rupture of the cell wall and membranes allows the release of the viral progeny previously formed, thereby enabling a subsequent infection of other bacteria.

Other features, besides bacterial lysis, which makes them attractive bacterial control agents are: i) their highhost specificity, decreasing the probability of generating dysbiosis ii) replication at the site of infection, which allows their presence in the most necessary moments of infection iii) clinical safety in higher organisms; the bacteriophages have been administered orally, rectally, dermally, parenterally (intramuscular, intravenous and intraperitoneal) and through aerosols, both in animals and human beings, without registering harmful effects in them (considering that many phages are commensal in them), iv) less probabilities to generate bacterial resistance in vivo, situation that can be further reduced with the simultaneous implementation of several phages (cocktail), and v) their selection and multiplication processes are relatively simple, rapid and of low cost (Sulakvelidze et al 2001, Garcia et al 2008).
Phages are highly ubiquitous, occupying all ecosystems where bacteria successfully develop. These agents have been isolated from shallow and deep water environments, soils, oral cavity, blood and guts of healthy humans and animals (Gorski and Weber-Dabrowska 2004). For example, they have been found in soil concentrations of 0.7 to $2.7 \times 10^{8} \mathrm{PFU} / \mathrm{g}$ and the ratio "phage:bacterium" can be as high as 100 , while in the intestine of healthy humans the titers can become higher than $10^{7} \mathrm{PFU} / \mathrm{g}$ (Gorski and Weber-Dabrowska 2004). They have also been isolated from a variety of foods such as lettuce, chilled and frozen crabs, beef and pork, oysters, mussels, mushrooms, cakes, biscuits dough and bread, raw and roasted chicken and turkey, milk, cheese, yogurt, butter and sardines (Hudson et al 2005, Hagens and Loessner 2007 Ceyssens and Lavigne 2010). This suggests that daily consumption of phages may be an important natural strategy to restabilise the intestinal population of phages and regulate colon microbalance (Sulakvelidze and $\mathrm{Ba}-$ rrow 2005).

\section{GENERAL CONSIDERATIONS OF PHAGE THERAPY IN ANIMAL MODELS: ADVANTAGES AND DISADVANTAGES}

Since their discovery lytic phages were used first as therapeutic agents and then as prophylactic agents in animals and in food biocontrol. Thus, their first use dates back to 1919 when D'Herelle proved their efficacy in children suffering from dysentery caused by Shigella spp in a french pediatric hospital (Sulakvelidze et al 2001, Summers 2001). Six years later, the success was repeated on patients with bubonic plague in Egypt and on cholera patients in India where the mortality was reduced from 30\% to 0\% (Sulakvelidze and Kutter 2005). At the same time, in 1921 phages were used for treating skin infections caused by Staphylococcus spp (Kutter and Sulakvelize 2005). Despite the above, the positive results of D'Herelle were not always repeated. After these promising results, phages continued to be used both in human and veterinary medicine, using many commercial preparations available at that time. However, with time some drawbacks were presented, such as presence of toxic contaminants including endotoxin in the preparations, stability and viability deficiencies, and the phenomena of bacterial phage resistance (Sulakvelidze et al 2001). Along with all these problems and coupled with the discovery and efficacy of antibiotics, phage therapy was downplayed as a therapeutic measure. Studies continued almost exclusively in Eastern Europe, primarily in the former Soviet Union (mainly on the Eliava Institute in Georgia, considered as a pioneer in the application of phage therapy and subsequent research) and Poland, where they use phage therapy in children with dysentery, showing a 3.8-fold decrease in the incidence of the treated group compared with the group that received only a 
placebo (Sulakvelidze and Kutter 2005). At that time, the behaviour of phages against Shigella spp, Klebsiella spp, Pseudomonas spp, Proteus spp, E. coli, Staphylococcus spp, Streptococcus spp and Salmonella spp was also studied, all of them showing some degree of success in patients. Moreover, the study of phages in Western countries was shelved by the inconsistency of the results of many bacteriophages therapeutic trials. Currently, it is accepted that the major cause of these failures was the poor understanding of the biology of these agents and other issues, such as quality control during preparation of therapeutic stocks (Summers 2001). Along with this, the discovery of antibiotics and their subsequent massive utilization displaced investigations in phage therapy.

Over time, the abuse of antimicrobials in the area of public health and animal production made unavoidable a large-scale development of bacterial resistance to these substances and thus, an urgent need to find new substances, chemical or biological that could control the diseases without inducing disease resistance again. Facing this dilemma, the old idea of using phage therapy against bacterial diseases was reborn. The pioneers in using phage therapy in animal models were William Smith and his colleagues of the "Institute for Animal Disease Research" in Houghton, Britain. They began their studies in mice experimentally infected with $E$. coli, where they observed that a single dose of phage decreased the bacterial counts. Later they repeated it in calves, lambs and guinea pigs infected with a diarrheogenic strain of E. coli, where phage therapy reduced the presence of the bacterium in the digestive tract and also associated symptoms such as the loss of fluids. In this study they obtained a survival of $100 \%$ of the infected animals (Sulakvelidze et al 2001). These results marked an important landmark in Western European studies, enhancing thus phage therapy scientific research in animals infected with multi-resistant bacteria, such as Pseudomonas aeruginosa, Acinetobacter spp and Klebsiella spp.

Phage therapy, like any other therapeutic method, has advantages and disadvantages mainly related to antibiotic therapy. Among the advantages the following are described:

- Exclusively bactericidal capacity: bacteria that have been successfully infected by lytic phages are unable to regain viability. In contrast, few antimicrobials have bacteriostatic action only, and as a result they may allow the evolution of bacterial resistance (LocCarrillo and Abedon 2011).

- Exponential growth of viral particles: during bacterial cell death, phages are able to increase their numbers specifically where the host is located, with some limitations such as their relatively high dependence on bacterial concentration (Loc-Carrillo and Abedon 2011). The kinetics of phage action in contrast to antimicrobials rests in their ability to self-replicate; thereby, effects are achieved with only a small initial inoculum and with a lower number of doses compared to antibiotic therapy (Payne and Jansen 2001).

- Minimal effects on normal microflora: because of their close host specificity, which may include the ability to infect a few strains or bacterial species, more rarely, the ability to infect more than one genus, closely related to each other. In contrast, many antimicrobial chemicals that possess a wide spectrum of activity are likely to generate superinfections, such as Clostridium difficile antibiotic-associated colitis, or infection by Candida albicans (Loc-Carrillo and Abedon 2011).

- Reduced potential to induce bacterial resistance: bacteria expressing mutations can generate resistance to lytic phages (Carlton 1999). Skurnik and Strauch (2006) indicated that in a bacterial population of $10^{6}$ $10^{8}$ colony forming units (CFU), there is a high possibility of finding mutant, phage-resistant bacteria with a mutated receptor that is not recognised by the virus. This situation is not always disadvantageous, since if the mutated receptor corresponds to a virulence factor (e.g. LPS), the bacteria could reduce or even lose their virulence, if factors associated with their adaptability to the environment were modified (Skurnik and Strauch 2006, Capparelli et al 2010). A strategy has been developed that consists in administering phage mixtures, minimising the possibility that bacteria may evolve resistance to all bacteriophages comprising the phage cocktail (Borysowski et al 2006, Loc-Carrillo and Abedon 2011). Regarding this subject, antibiotics have a clear limitation because they are stable, immutable chemicals and therefore are unable to adapt to bacterial mutations (Carlton 1999), along with the undeniable evidence that most antibiotic substances have already generated bacterial resistance.

- Lack of cross-resistance to antibiotics: because phages infect and kill bacteria using different mechanisms to those of antibiotics, mechanisms specific to the latter are not translated into phage resistance mechanisms. Consequently, phages can be effectively used to treat antibiotic-resistant infections such as those caused by multidrug-resistant Staphylococcus aureus (Loc-Carrillo and Abedon 2011). This differs significantly from antibiotic resistance, as many mechanisms of resistance to any particular family of antibiotics can also affect the effectiveness of different classes of antibiotics.

- Non toxic effects: some toxicity studies performed with phages in experimental animals such as chickens and mice have shown no toxic effects or adverse reactions in animals (Xie et al 2005, Gill et al 2006). Furthermore, they are recognised to be harmless to humans and animals, since recently their use has been approved as an additive in human foods and for direct application in animals (Carlton et al 2005). Currently, the commercial preparation ListShield ${ }^{\mathrm{TM}}$ of Intralytix company (Monk et al 2010), consisting of a mixture 
of six phages acting against Listeria monocytogenes, was approved by the Food and Drug Administration (FDA) for use in meat and ready to eat poultry products. Another product acting against L. monocytogenes, approved by the FDA is LISTEX ${ }^{\mathrm{TM}} \mathrm{P} 100$, of the company EBI Food Safety (Monk et al 2010), which in 2007 expanded its use to all food contamination with this bacterium, gaining GRAS product category (Generally Recognised as Safe) (Carlton et al 2005, Bren 2007). For E. coli O157:H7, the company Intralytix offers its product EcoShield ${ }^{\mathrm{TM}}$ for use in contaminated food (Monk et al 2010) while OmniLytics Inc. has a product to treat live animals for slaughter, either based on shower (livestock) or spray (poultry) (OmniLytics 2007). To elucidate the big question of the potential effect of phages on eukaryotic cells several studies of genetic engineering have been performed. In these, a hybrid phage was able to enter a mammalian cell but was unable to replicate, concluding that the specificity of the phage is given not only by a specific receptor, but also by the bacterial enzymatic machinery (Dabrowska et al 2005). In contrast, certain antibiotics such as tetracyclines and gentamycin exhibit toxic effects after prolonged administrations, in young individuals or in certain physiological states such as pregnancy.

- Possible phage transfer between individuals: this is essentially cross infection of phages from treated subjects or environments to untreated individuals, which may be potentially useful in agricultural applications (Fiorentin et al 2005, Rozema et al 2009, Loc-Carrillo and Abedon 2011).

- Low environmental impact: because of their chemical composition and their narrow host range, phage eliminated after treatment, unlike broad-spectrum antibiotics, in the worst scenario will impact only a small group of environmental bacteria (Loc- Carrillo and Abedon 2011).

- Low cost: the production of phages predominantly involves growth in its host and further purification. While the cost of growing the virus in its host varies depending on the bacterial type, the cost of purification seems to be diminishing as technologies improve. Overall production costs of phages, per unit, do not compare to the costs of the pharmaceutical production, while the cost of discovery, isolation and characterization can be relatively low (Loc-Carrillo and Abedon 2011).

Otherwise, within the major concerns and disadvantages of using phages as therapeutic agents the following are described:

- Existence of phage-resistant bacteria: bacteria can evolve resistance to bacteriophages through a variety of mechanisms, including the blocking of viral ad- sorption by block or loss of receptors, extracellular matrix production and/or production of competitive inhibitors (Labrie et al 2010, Buckling and Brockhurst 2012), inhibition of the viral genome injection by the phage superinfection exclusion mechanism (Labrie et al 2010, Buckling and Brockhurst 2012, Nechaev and Severinov 2008), restriction-modification systems mediated by enzymes that degrade viral nucleic acids or the CRISPR-Cas system (Bikard and Marraffini 2011, Martinez-Borra et al 2012, Sashital et al 2012, Stern and Sorek 2011), and infection abortion systems of resistance conferred by the Abi system (Buckling and Brockhurst 2012, Martinez-Borra et al 2012). In vitro monoculture studies have shown that bacterial resistance to phages can be generated in hours to days. However, to date it has not been clarified whether the development of this resistance in vitro is relevant under in vivo conditions. One of the main strategies to prevent and reduce this phenomenon is the use of mixtures of different bacteriophages, which has shown good results (Tanji et al 2005, LocCarrillo and Abedon 2011).

- Not all phages are good therapeutic agents: good therapeutic phages must have a high potential to reach and then kill the bacteria, along with a low potential to modify adversely the environments in which they are applied. These characteristics can be guaranteed if the phages used are strictly lytic, stable under storage conditions and temperatures, subjected to appropriate safety and efficacy studies, and ideally be fully sequenced to confirm the absence of undesired genes such as toxin encoding genes. The characterisation of phages can include virion morphology, protein profiles or genotypic characterization other than sequencing, etc., although the costs associated with this exhaustive characterisation can be restrictive. Therefore, the main objective should be to identify those phages that exhibit favorable pharmacodynamic characteristics (e.g. antibacterial efficacy), and good pharmacokinetic properties (ability to reach the bacteria in situ). Those phages that do not satisfy adequately this criterion should not be used as therapeutic agents (Loc-Carrillo and Abedon 2011). In the case of intracellular living bacteria such as Salmonella, which invades its target cell and is therefore protected from the action of bacteriophage by the Salmonellacontaining vacuole, it is suggested that the bacteria must be removed by the phages before it can invade its eukaryotic host animal (Sklar and Joerger 2001).

- Narrow host range: the narrow host range of phages could constitute, at least, a limitation for presumptive treatment. However, as phages may be used in combination with other antimicrobial agents, including other phages, the lytic spectrum of these particles can be much broader than the spectrum of activity of a single phage (Loc-Carrillo and Abedon 2011). 
- Need of high bacterial concentration: this is a needed requirement for the phage to replicate and lyse bacteria. If they are administered in a hurry they will tend to inactivate due to lack of bacteria and higher concentrations will be needed later (Payne and Jansen 2001). To indicate the relation between the phage and the concentration of target bacteria present, the term multiplicity of infection (MOI) is established, which Abedon and Thomas-Abedon (2010) defined as the "relationship established between the concentration of phage (in PFU) and the concentration of the target bacteria (expressed in CFU) in a given volume", existing a direct relationship between the effectiveness of the phage and the MOI employed. In this regard, Joerger (2003) notes that the use of phage therapy necessarily requires a high MOI, meaning a greater phage titer compared with the titer of its target bacterium. Thus, the use of a MOI of at least 10,000 times has been validated by previous national investigations, which have used the same bacterial strain obtaining successful results using such bacteriophage-bacteria proportion in poultry infection trials (Borie et al 2008a, Borie et al 2008b, Borie et al 2011).

- Bacteriophage ability to induce humoral and cellular immune responses in organisms: there have been found bacteriophages neutralising antibodies in serum from different animal species and colostrum of cows that have not been stimulated by phagetherapy. Only some bacteriophages are antigenic and elicit high titers of anti-phage antibodies, a situation that would seem to be a disadvantage in phagetherapy. The phage-antibody reaction depends on time and the phage traits (Dabrowska et al 2005). For this reason, Carlton (1999) suggested the administration at high doses to compensate antibody neutralization.

- Interaction of bacteriophages with the innate immune system: this interaction is very important for phage removal in higher organisms, and may lead to low efficiency of phage therapy (Dabrowska et al 2005). It is recognised that this may be the greatest problem in the effectiveness of the therapy since it has been shown that phages administered once, are reduced by more than $90 \%$ in the circulatory system and, although it has been postulated that antibodies can be the major factor in removing the phage, it has been determined in mice never exposed to bacteriophages that the reticuloendothelial system is sufficient and highly effective in the removal of bacteriophages (Merril et al 1996).

- Existence of physical and chemical barriers which may reduce the phage-bacterium interaction: an example of this has been observed in orally administered phage therapies, where the gastrointestinal environment determines a decrease in the effective encounter between the bacteriophage and the challenge strain (Sklar and Joerger 2001), since the virus can experience structural problems due to action of digestive enzymes and $\mathrm{pH}$ conditions found in the gastrointestinal tract (Higgins et al 2007). Also, studies have shown that translocation of bacteriophages to the bloodstream is less effective when they come from the stomach than when they come from other sections of the gastrointestinal tract. It is known that some bacteriophages cannot survive if exposed to pH 2 versus $\mathrm{pH} 3$ to $\mathrm{pH} 7$ wherein titers diminish. However, the sensitivity to low $\mathrm{pH}$ values depends on the type of bacteriophage (Dabrowska et al 2005). Moreover, neutralizing stomach acid with antacid substances before administration of bacteriophages appears to be an important factor for maintaining them (Smith et al 1987, Koo et al 2001, Atterbury et al 2007, Higgins et al 2007). Another physical barrier to be considered in oral phage therapies is viscosity. Joerger (2003) describes that the viscosity of the intestinal content appears to reduce the probability of contact between bacteria and bacteriophages. Additionally, the large number of bacteria present in certain segments of the intestinal tract may be a mechanical barrier to the spread of bacteriophages. However, it is presumable that the physical effect of these barriers may be offset, in part, by increasing the number of phages administered. In fact, the use of phage therapy necessarily requires high multiplicities of infection.

- Limited knowledge about the kinetics of phage: this proves to be another big issue (Dabrowska et al 2005), since some critical parameters for phage therapy must be considered, such as the phage adsorption rate, the number of replication cycles, the latency period, the initial dose of phage and their elimination by the reticuloendothelial system (Skurnik and Strauch 2006).

- Consumer perception problems: this disadvantage is related to the use of these agents in food-borne pathogen biocontrol and not for their use in phage therapy itself. The presence of viruses in food could cause consumers to be reluctant to eat foods that were treated at different times of their production with bacteriophages. This situation would be resolved by educating consumers about the safety of the use of phages, and also through the use of new molecules derived from phages, such as endolysins or purified lysozyme (Borysowski and Weber-Dabrowska 2008).

\section{PHAGE THERAPY IN VETERINARY MEDICINE}

In veterinary medicine, the first published investigation dates from 1941, where Slanetz and Jawetz isolated and characterised phages against staphylococci from cow's milk, to study their effectiveness against mastitis caused by these pathogens, using cats and rabbits as experimental models. The results of this pioneering research lead to suggest a priori, the ineffectiveness of 
phages against clinical mastitis by Staphylococcus spp (Slanetz and Jawetz 1941). Thereafter, and despite the initial results, researches in different animal species and against many bacterial pathogens have been published, with emphasis on those agents associated with foodborne diseases (table 1).

\section{PHAGE THERAPY AGAINST DISEASES CAUSED BY PATHOGENIC E. COLI STRAINS}

E. coli pathogenic strains are known to affect many animal species including chickens, cattle, sheep and goats, as well as pets. Diseases caused by this group of

Table 1. Some in vivo studies of phage therapy in Veterinary Medicine. Algunos estudios in vivo de fagoterapia en Medicina Veterinaria.

\begin{tabular}{|c|c|c|c|c|}
\hline Bacterial target & Animal & Phage treatment effect & Phage strategy & Authors \\
\hline S.Typhimurium & Swine & $\begin{array}{l}\text { Reduction of the bacterial count from tonsils and cecal } \\
\text { content }\end{array}$ & $\begin{array}{l}\text { Single phage } \\
\text { (Felix-O1) }\end{array}$ & Lee and Harris 2001 \\
\hline S.Typhimurium & Swine & Bacterial count reduction in several organs and tissues & $\begin{array}{l}\text { Single phage } \\
(\text { Felix-O1) }\end{array}$ & Lee and Harris 2003 \\
\hline S.Typhimurium & Piglets & Cecum and ileal bacterial reduction & Phage mixture & Wall et al 2010 \\
\hline S.Typhimurium & Chicken & Reduction of the cecal bacterial counts & Phage mixture & Fiorentin et al 2005 \\
\hline S.Typhimurium & Chicken & $\begin{array}{l}\text { Reduction of the cecal bacterial counts, but no effect in } \\
\text { ileum, spleen and liver count }\end{array}$ & Phage mixture & Toro et al 2005 \\
\hline$S$. Enteritidis & Chicken & Reduction of bacterial counts from cecal tonsils & Single phage & Filho et al 2007 \\
\hline $\begin{array}{l}S . \text { Enteritidis and } \\
S . \text { Typhimurium }\end{array}$ & Chicken & Reduction of cecal bacterial counts & Single phage & Atterbury et al 2007 \\
\hline$S$. Enteritidis & Turkey & No cecal bacterial count reduction & Phage mixture & Higgins et al 2007 \\
\hline$S$. Enteritidis & Chicken & Intestinal reduction by phage spray treatment & Phage mixture & Borie et al 2008(a) \\
\hline$S$. Enteritidis & Chicken & Intestinal bacterial counts reduction & Single phage & Borie et al 2008(b) \\
\hline S. Enteritidis & Hens & $\begin{array}{l}\text { No reduction in the incidence of reproductive tissue } \\
\text { colonization, with a slight decrease in the bacterial } \\
\text { count in ovary }\end{array}$ & Phage mixture & Borie et al 2011 \\
\hline$S$. Enteritidis & Chicken & Significantly lower bacterial counts in cecal tissue & Single phage & Lim et al 2012 \\
\hline C. jejuni & Chicken & Intestinal bacterial counts reduction & Phage mixture & Wagenaar et al 2005 \\
\hline C. jejuni & Chicken & Reduction in cecal bacterial counts & Phage mixture & Loc-Carrillo et al 2005 \\
\hline $\begin{array}{l}\text { C. jejuni and } \\
\text { C. coli }\end{array}$ & Chicken & Reduction in cecal bacterial counts & Phage mixture & Carvalho et al 2010 \\
\hline S. aureus & Cows & No significantly bacterial reduction in udder & Single phage & Gill et al 2006 \\
\hline P. aeruginosa & Dogs & $\begin{array}{l}\text { Decrease in clinical score of chronic otitis and reduction } \\
\text { in bacterial counts }\end{array}$ & Phage mixture & Hawkins et al 2011 \\
\hline E. coli $\mathrm{K}^{+}$ & $\begin{array}{l}\text { Calves and } \\
\text { chicken }\end{array}$ & $\begin{array}{l}\text { Mortality rate reduction, delayed appearance of } \\
\text { bacterium in the blood and lengthened life span in } \\
\text { calves. } \\
\text { Count reduction in chicken brain, blood and spleen. }\end{array}$ & Single phage & Barrow et al 1998 \\
\hline E. coli $\mathrm{O} 2$ & Chicken & Mortality rate reduction in day-dependent way & Phage mixture & Huff et al 2003 \\
\hline $\begin{array}{l}\text { Enteropathogenic } \\
\text { E. coli }\end{array}$ & Chicken & Diarrhea incidence and mortality rate decrease & Single phage & Xie et al 2005 \\
\hline E. coli $\mathrm{O} 157: \mathrm{H} 7$ & $\begin{array}{l}\text { Sheep and } \\
\text { steers }\end{array}$ & $\begin{array}{l}\text { Intestinal bacterial count reduction in steers, but no in } \\
\text { sheep }\end{array}$ & $\begin{array}{l}\text { Single and } \\
\text { phage mixture }\end{array}$ & Sheng et al 2006 \\
\hline E. coli $\mathrm{O} 157: \mathrm{H} 7$ & Sheep & No bacterial count reduction in feces & Single phage & Bach et al 2003 \\
\hline E. coli $\mathrm{O} 157: \mathrm{H} 7$ & Sheep & Bacterial count reduction in feces, cecum and rectum & Phage mixture & Callaway et al 2008 \\
\hline E. coli $\mathrm{O} 157: \mathrm{H} 7$ & Sheep & Bacterial count reduction in gastrointestinal tract & Phage mixture & Raya et al 2011 \\
\hline $\begin{array}{l}\text { E. coli and } A \text {. } \\
\text { pyogenes }\end{array}$ & Cattle & No reduction in uterine isolation rate & Phage mixture & Machado et al 2012 \\
\hline
\end{tabular}


bacteria in livestock have a large economic impact by decreasing the efficiency of feed conversion and causing mortality, along with being a potential source of infection for humans (or other animals) that consume their derived products, as is the case of E. coli $\mathrm{O} 157: \mathrm{H} 7$.

There are several phage therapy studies in experimentally infected chickens with pathogenic $E$. coli (Barrow et al 1998, Huff et al 2003, Xie et al 2005) causing diarrhea, septicemia, meningitis, and consequent mortality. In these studies, the application of these viruses was able to reduce the incidence of diseases, and more importantly, decrease in the mortality rates up to $79 \%$. In these experiments different MOI were used, different routes of administration (intramuscular and oral), mostly coinciding that the intramuscular route produced greater reductions in bacterial counts or mortality/morbidity, with rising phage concentration and the corresponding MOI.

One of the main livestock species considered as a reservoir of pathogenic E. coli, specifically E. coli $\mathrm{O} 157: \mathrm{H} 7$, is cattle. Several studies on phage efficiency for the elimination or reduction in carriage of these intestinal bacteria have been performed (Sheng et al 2006, Rozema et al 2009). Sheng et al (2006) concluded that a continuous phage therapy can be an effective method to reduce $E$. coli O157: H7 carriage, achieving significant reductions in vivo up to $1.5 \log$ lower compared with the control group. Regarding sheep studies, there are reports of Bach et al 2003, Callaway et al 2008, Raya et al 2011, among others. In these, they attempt to reduce or eliminate the pathogen from the gastrointestinal system. The removal in rumen showed good results, as in the intestinal tract and feces, achieving reductions up to $>99 \%$ compared to animals without phage treatment. Although ruminal food particles can affect the effectiveness of the phage, to date the results support the conclusion that appropriately selected phages can be used to reduce $E$. coli $\mathrm{O} 157: \mathrm{H} 7$ in ruminants under a control program of this food-borne pathogen.

Recently, Machado et al (2012) used a mixture of four different bacteriophages in lactating cows to determine their possible effect on fertility and uterine health. To do this, they applied an intrauterine dose of $10^{7} \mathrm{PFU}$, performing an active search of E. coli and Arcanobacterium pyogenes in uterine samples. At different times post treatment, no effect was found on uterus health, neither on reproductive performance or the presence of both bacterial pathogens.

\section{PHAGE THERAPY AGAINST DISEASES CAUSED BY SALMONELLA SPP}

One of the most important pathogens in animal production systems is Salmonella. Certain strains or serotypes can cause serious economic damage resulting from the disease and eventual mortality, with serious consequences for public health due to the production of Salmonella contaminated food.
Regarding the control of Salmonella spp in swine farms, Lee and Harris (2001) conducted a study in which a specific lytic phage against Salmonella (Felix-O1) was tested as a possible candidate for Salmonella Typhimurium control. In this research, the phage treatment significantly reduced the bacterial count from tonsils and cecal content as compared to the control group. In a subsequent study (Lee and Harris 2003), a protocol of multiple doses administered 24 hours prior to shipment and profit was set up, showing that this protocol can reduce concentrations of $S$. Typhimurium in several organs and tissues. However, intramuscular administration may not be practical in modern pig production (Johnson et al 2008). Following this line, Wall et al (2010) developed a series of tests to measure whether phage therapy could limit $S$. Typhimurium infections in pigs during transport and pre-slaughter maintenance, considered one of the most likely contamination stages for the animals. The results of this study showed that using a phage mixture allowed significant cecal concentration reduction (1.5 log CFU/ $\mathrm{mL}$ versus $2.9 \log \mathrm{CFU} / \mathrm{mL}$ ) of this pathogen, also reducing its concentration in ileum $(1.7 \log \mathrm{CFU} / \mathrm{mL}$ versus $2.7 \mathrm{CFU} / \mathrm{mL}$ ). These results indicate that the use of phage to prevent Salmonella spp pork carcass contamination with bacterial agents is a promising and useful control strategy.

Otherwise, most studies trying to lessen the bearing of this intestinal pathogen have been made in commercial poultry, including chickens (Fiorentin et al 2005, Toro et al 2005, Atterbury et al 2007, Filho et al 2007, Borie et al 2008, Borie et al 2008 ) turkeys (Higgins et al 2007) and laying hens (Borie et al 2011).

In chicks studies by Fiorentin et al (2005) and Toro et al (2005) the administration of bacteriophage mixtures in birds previously inoculated with $S$. Typhimurium yielded lower cecal bacterial counts (up to six times less). However, Toro et al had different results working with phages in the ileum, spleen, liver and ceca. In this experience the use of phage at an early age (11 days) resulted in a significant reduction of Salmonella cecal counts, approximately 10 times compared to the infection control group; however, no significant reductions were achieved in the other tissue samples. Using phage against $S$. Enteritidis, Filho et al (2007) were able to significantly reduce bacterial counts (up to 65\%) of the pathogen from cecal tonsils at 24 hours post treatment relative to the 1 day chicks control group.

Phage therapy in older chickens has also been investigated. Atterbury et al (2007) orally infected 36 day-old broiler chickens with $S$. Enteritidis or $S$. Typhimurium. Two days post-infection, the birds were treated with bacteriophage. The birds treated with bacteriophage showed a significant reduction ( $\geq 4.2 \log \mathrm{CFU}$ ) in average $S$. Enteritidis and $S$. Typhimurium cecal count regarding infection control groups at 24 hours post treatment, supporting also the effectiveness of using phages in older chickens. 
Additionally, Higgins et al (2007) evaluated the effectiveness of a gastrointestinal $\mathrm{pH}$ adapted phage mix in reducing $S$. Enteritidis in 2 day-old turkey's ceca, using two different viral and bacterial concentrations. They obtained cecal bacterial count reductions, however, these reductions in both experiences were not statistically different.

In a study by Borie et al (2008), authors assessed the preventive effect of a mixture of three bacteriophages, dosed by spraying and drinking water, to reduce Salmonella colonization in chickens. The incidence of Salmonella contamination in intestine was significantly reduced by the treatment of bacteriophage through spray, showing an intestinal reduction of the pathogen, whereas in chicks treated with bacteriophage via drinking water did not change counts significantly when compared to the control group, although it did produce a decrease in intestinal count (reduction of $1.42 \mathrm{CFU} / \mathrm{g}$ by drinking water and $1.63 \mathrm{CFU} / \mathrm{g}$ by spraying). These results indicate that some bacteriophage treatments can reduce the incidence of intestinal infection and the bacterial count. Furthermore, it was determined that the route of administration of phages plays an important role in the success of treatment. Simultaneously, Borie et al $\left(2008^{\mathrm{b}}\right)$ evaluated the effect of the administration of a single bacteriophage in the prevention of intestinal colonization in White Leghorn chickens in a protocol similar to the previous one, showing that the virus concentration and the MOI is essential to significantly reduce bacterial counts.

In addition to evaluating the effectiveness in young chickens, Borie et al (2011) examined the ability of a mixture of three bacteriophages to reduce the incidence of infection and $S$. Enteritidis counts in the reproductive tract of chickens. The results showed that, although bacteriophages are able to reach ovary and oviduct, they do not reduce the incidence of bacterial colonization locally. On the other hand, regarding the count of the pathogen, only a slight significant decrease was achieved, compared with the control group. In the study, no bacteriophages were isolated in eggs from infected and treated hens, indicating that its effectiveness is still unclear when dosed orally.

Recently Lim et al (2012) measured the effectiveness of administration of phages as additives in food, in 1 dayold chicks for the reduction of $S$. Enteritidis infection. In this study, using different viral concentrations, only the administration of a high phage concentration $\left(10^{9} \mathrm{PFU} / \mathrm{g}\right)$ achieved significantly lower counts of Salmonella in cecal tissue compared to the control group (5.48 log CFU/g in contrast with $6.55 \log \mathrm{CFU} / \mathrm{g}$ ), demonstrating their effectiveness.

\section{PHAGE THERAPY TO CONTROL CAMPYLOBACTER SPP. IN ANIMALS}

Another bacterial pathogen that has a great importance in poultry production flocks, mainly because of its potential impact on consumers, is Campylobacter spp. Wa- genaar et al 2005, Loc-Carrillo et al 2005 and Carvalho et al 2010, among others, reported on the efficiency of using bacteriophages to diminish intestinal carriage of $C$. jejuni and $C$. coli. Wagenaar et al (2005) evaluated the preventive and therapeutic effect of two lytic bacteriophages on $C$. jejuni intestinal colonization in broiler chicks. In a first trial, the birds received a mixture of phages orally for 10 days, with doses ranging from $4 \times 10^{9}$ to $2 \times 10^{10} \mathrm{PFU}$; at day 5 of the experiment, birds were challenged orally with $1 \times 10^{5} \mathrm{CFU}$ of $C$. jejuni. This treatment did not prevent intestinal colonization of the bacteria, but did reduce it by $2 \operatorname{logs}$ compared to the control infection group. In a second trial, the birds received the mixture of phages orally, from days 5 to 11 post bacterial inoculation, at doses similar to the first experiment. The results of this assay showed an immediate reduction in $3 \log$ units on the cecal counts of bacteria in the treated birds, although after 5 days the counts stabilized at $1 \log$ below the infection control group. In turn, Loc-Carrillo et al (2005) evaluated the therapeutic effect of bacteriophages CP8 and $\mathrm{CP} 34$ on $C$. jejuni intestinal colonization. For this, broilers from 20-22 days-old were orally challenged with 2.7 to $7.8 \log _{10}$ CFU of $C$. jejuni. At the age of 25 days, the chickens individually received bacteriophages orally, in an antiacid suspension, at a dose of $9.5 \log _{10}$ PFU. Results showed that the phagetherapy achieved a reduction in cecal bacterial counts from 0.5 to $5 \log _{10} \mathrm{CFU} / \mathrm{g}$ of cecal content, compared to the untreated group. Carvalho et al (2010) obtained similar reductions (approximately $2 \log _{10} \mathrm{CFU} / \mathrm{g}$ in faeces) in one day-old broiler chickens experimentally inoculated with $C$. jejuni and C. coli and dosed orally, at a week-old age, with a cocktail of phages associated with an antiacid. Bacterial reduction was observed 48 hours post phage administration in food and persisted until the end of the experiment (seven days).

The results of the investigations on $C$. jejuni support the use of these viruses to reduce carcass contamination that occurs in poultry slaughtering plants from intestinal contents, thereby decreasing the probability of marketing contaminated products.

\section{PHAGE THERAPY AGAINST DISEASE CAUSED BY STAPHYLOCOCCUS AUREUS}

While specific bacteriophages have been isolated against $S$. aureus strains, their lytic activity in vitro suggests their use to control many pathologies. However, there are rare and inefficient animal phage therapy trials, as noted in 1941 by Slanetz and Jawetz for bovine clinical mastitis. A study performed in 2006, proved the poor efficiency of phage therapy against subclinical mastitis caused by $S$. aureus, after selecting 24 cows, with positive cultures for methicillin-resistant S. aureus (MRSA). Cows were intramammary dosed with $10 \mathrm{~mL}$ of a bacteriophage named $\mathrm{K}$, at a dose of $1.25 \times 10^{10} \mathrm{UFP}$; phage doses were administered once daily for 5 consecutive days. Fi- 
nally, it was shown that out of 18 udders studied, only 3 $(16.7 \%)$ were negative for the presence of the pathogen. These results were not statistically significant. This was attributed, at least partially, to phage inactivation in the milk of the udder (Gill et al 2006).

\section{PHAGE THERAPY IN COMPANION ANIMALS}

In pets, specifically dogs and cats, there are few studies that furnish clinical evidence, even though an excellent in vitro lytic activity of certain bacteriophages against bacteria isolated from pets has been demonstrated. This is the case of a report by Santos et al (2011), who showed strong antimicrobial activity of phages P2S2 and P5U5 against 26 strains of Pseudomonas aeruginosa isolated from dogs with keratitis. Hawkins et al (2010) used a mixture of 6 active phages against $P$. aeruginosa in 10 dogs with chronic otitis refractory to antimicrobial therapy against the causative agent $P$. aeruginosa. Bacteria were sensitive to at least one of the phages under study. The application of phages was by direct instillation into the ear canal and its efficiency was measured by bacterial counting from otic swabs at 48 hours post treatment. A decrease in clinical score (of 100 to $30.1 \%$ ), a reduction in counts (from 100 to $67 \%$ ) and a rise in phage average titer of 100 times was found. Tracking of the animals 18 months after therapy was incomplete but generally positive, showing no collateral effects due to phage therapy.

Regarding the potential treatment of extraintestinal cases produced by E. coli in pets, Freitag et al (2008) investigated the feasibility of phage therapy to combat urinary tract infections caused by E. coli in dogs and cats. For this purpose, they measured the efficiency, in vitro, of 40 phages on 53 uropathogenic E. coli strains (UPEC). In total, 94\% of UPEC strains were lysed by one or more phages. Therefore, these results indicate that most of UPEC strains are susceptible to lysis by bacteriophages thus becoming a therapeutic promise for the treatment of urinary tract infections in dogs and cats.

\section{PHAGE THERAPY IN AQUACULTURE}

In these animal production systems, the search for different therapeutic alternatives to antibiotics is a mandatory issue due to the magnitude of antimicrobial resistance and environmental pollution caused by antibiotic therapy; also because there are few available drugs licensed for use in fish. This situation has led to studies on frequent pathogens such as Vibrio harveyi, Lactococcus garviae, Streptococcus iniae, Flavobacterium psychrofilum, Pseudomonas plecoglossicida, Aeromonas salmonicida, Aeromonas hydrophyla and Edwarsiella tarda (Nakai 2010). Recent studies in fish are rare and carried out by a small group of researchers, so that there is still no conclusive evidence. Even though phage therapy effectiveness in fish has not always been observed, there are some encouraging studies.
Their results indicate reduction in mortality and clinical signs of the disease and increase in survival. Typically, phages are detected in tissues where the bacteria are found in less than 24 hours post application (orally, intraperitoneally or by immersion) allowing to obtain results readily, although not always efficient (Nakai 2010). Pereira et al (2011) analysed lytic phages against certain fish pathogens together with their effect on the bacterial community structure of the aquaculture facilities and their time of survival in marine waters. In general terms, the phages monitored in this study (AS-1 and VP-1) did not alter bacterial diversity. Correspondingly, the bacterial ribotype cluster analysis revealed a high percentage of similarity $(>80 \%)$ in zero time water samples and water samples with and without phage incubated during 10 hours. The phages analised decreased their titer in aquaculture water at $25^{\circ} \mathrm{C}$ in a period between 12 to 91 days depending on the phage.

\section{DISCUSSION}

The use of bacteriophages as therapeutic agents in animals and to control food-borne diseases is a great potential new tool. Their properties and behavior in vitro strongly support their use (Loc-Carrillo 2011, Lu and Koeris 2011, Maura and Debarbieux 2011), including large-scale commercialisation, however, still further testing in vivo is needed to complement the large amount of information generated by in vitro studies. This need lies primarily in the efficiency differences that phage therapy has shown in certain experimental models, where the use of these agents in young animals is efficient, being this not necessarily consistent with studies in adult animals, such as hens (Borie et al 2011). These results, nevertheless, do not discredit the use of these viruses as therapeutic agents, but do emphasize that there are many factors that may prevent their proper function. Among these factors are included the administration route, initial bacterial dosage, phage concentration, etc., elements that should be fully understood in terms of interference with the effectiveness of bacteriophages in controlling bacterial pathogens.

Another important aspect to consider is the narrow host range of phages. In order to develop therapeutic or biocontroling tools, development of bacteriophages with a broader spectrum of activity should be a priority in the investigation of these agents. Despite this, this apparent weakness of phage can be remedied through the use of viral mixtures, thus extending their range of action.

Quality assurance in the massive use of this tool is, in their therapeutic role as well as their safety, a very important aspect to consider. This issue can be a major obstacle for its development, due to the time and resources required to be invested in, among other issues, sequencing the entire genome and study of pharmacokinetic and pharmacodynamic properties (Loc-Carrillo and Abedon 2011).

Despite the above mentioned, the approval of certain phage commercial formulations, such as those produced 
by Intralytics and Micreos Food Safety enterprises augur a promising future for phage therapy.

In a time when bacterial resistance to antibiotics is increasing, the use of bacteriophages has different advantages, along with relatively few disadvantages. The great advances in scientific knowledge about the biology of these agents, together with the development of the high level that medical research has achieved to date, can make the true potential of phage therapy fully understood and efficiently used.

To summarise considerations about phage therapy the recommendations made by Skurnik and Strauch (2006) are presented:

- Do not attempt the application of phagetherapy while the involved bacteriophage biology is not sufficiently understood.

- Bacteriophage preparations must fulfill all biosafety requirements, and must be free of bacteria and their components.

- Phage preparations should contain infective phage particles, whereby the storage of the preparations must be validated.

- Ideally, the bacteriophage receptor must be known. In a population of $10^{6}-10^{8}$ bacteria, there is a high probability of occurrence of spontaneous phage-resistant mutants, lacking it or with an altered structure.

- Phage therapy effectiveness must be tested in an animal model, since each bacteriophage can behave differently in vivo.

\section{CONCLUSIONS}

The studies presented in this review expose the great interest that has been generated by phage therapy throughout the years, and also in their effectiveness in reducing the colonisation of many pathogens in several tissues. While research began several decades ago, they have intensified in recent years due to the emergence of multiresistant bacterial strains and, of course, due to more information on these viral agents, allowing work on a much more solid knowledge base.

On the other hand, phage therapy remains controversial; however, rather than this being an impediment for research, it should be an incentive for new generations of scientists who are responsible for further investigation on bacteriophages, to safely determine whether these viruses are or not an optimal complementary tool to the use of other methods for bacterial growth control, such as antimicrobials.

\section{REFERENCES}

Abedon S, C Thomas-Abedon. 2010. Phage Therapy Pharmacology. Curr Pharma Biotechnol 11, 28-47.

Atterbury RJ, MAP Van Bergen, F Ortiz, MA Lovell, JA Harris, A De Boer, JA Wagenaar, VM Allen, PA Barrow. 2007.
Bacteriophage therapy to reduce Salmonella colonization of broiler chickens. Appl Environ Microbiol 73, 45434549.

Bach SJ, TA Mcallister, DM Veira, VPJ Gannon, RA Holley. 2003. Effect of bacteriophage DC22 on Escherichia coli O157:H7 in an artificial rumen system (Rusitec) and inoculated sheep. Anim Res 52, 89-101.

Barrow P, M Lovell, A Berchieri Jr. 1998. Use of lytic bacteriophage for control of experimental Escherichia coli septicemia and meningitis in chickens and calves. Clin Diagn Lab Inmunol 5, 294-298.

Bikard D, LA Marraffini. 2011. Innate and adaptive immunity in bacteria: mechanisms of programmed genetic variation to fight bacteriophages. Curr Opin Immunol 24, 15-20.

Boerlin P. 2010. Implications of antimicrobial agents as therapeutics and growth promoters in food animal production. In: Sabour P, Griffiths M (eds). Bacteriophages in the control of food- and waterborne pathogens. ASM Press. Washington, DC, USA, Pp 1-9.

Borie C, I Albala, P Sánchez, ML Sánchez, S Ramírez, C Navarro, MA Morales, J Retamales, J Robenson. 2008ª Bacteriophage treatment reduces Salmonella colonization of infected chickens. Avian Dis 52, 64-67.

Borie C, P Zurita, ML Sánchez, V Rojas, J Santander, J Robeson. $2008^{\mathrm{b}}$. Prevención de la infección por Salmonella enterica subespecie enterica serotipo Enteritidis (Salmonella Enteritidis) en pollos mediante un bacteriófago. Arch Med Vet 40, 197-201.

Borie C, C Hauva, J Quiroga, V Bravo, P Retamal, J Retamales, J Robeson. 2011. Uso de bacteriófagos en gallinas de postura infectadas con Salmonella enterica serotipo Enteritidis: prevención de la colonización intestinal y reproductiva. Arch Med Vet 43, 85-89.

Borysowski J, B Weber-Dąbrowska, AJ Górski. 2006. Current status and perspectives of phage therapy. Adv Clin Exp Med 15, 575-580.

Borysowski J, B Weber-Dabrowska. 2008. Bacteriophage endolysins as a novel class of antibacterial agents. $J$ Exp Biol Med 231, 366-377.

Bren L. 2007. Bacteria-eating virus approved as food additive. FDA Consumer Magazine 41, 20-22.

Buckling A, M Brockhurst. 2012. Bacteria-virus coevolution. Adv Exp Med Biol 751, 347-370.

Callaway TR, TS Edrington, AD Brabban, RC Anderson, ML Rossman, MJ Engler, MA Carr, KJ Genovese, JE Keen, ML Looper, EM Kutter, DJ Nisbet. 2008. Bacteriophage isolated from feedlot cattle can reduce Escherichia coli O157:H7 populations in ruminant gastrointestinal tracts. Foodborne Pathog Dis 5, 183-191.

Capparelli R, N Nocerino, M Iannaccone, D Ercolini, M Parlato, M Chiara, D Iannelli. 2010. Bacteriophage therapy of Salmonella enterica: a fresh appraisal of bacteriophage therapy. J Infect Dis 201, 52-61.

Carlton RM. 1999. Phage therapy: past history and future prospects. Arch Immunol Ther Experiment 47, 267-274.

Carlton RM, WH Noordman, B Biswas, ED De Meester, MJ Loessner. 2005. Bacteriophage P100 for control of Listeria monocytogenes in foods: genome sequence, bioinformatic analyses, oral toxicity study, and application. Regul Toxicol Pharmacol 43, 301-312.

Carvalho CM, BW Gannon, DE Halfhide, SB Santos, CM Ha- 
yes, JM Roe, J Azeredo. 2010. The in vivo efficacy of two administration routes of a phage cocktail to reduce numbers of Campylobacter coli and Campylobacter jejuni in chickens. BMC microbiology 10, 232-243.

CDC, Centers for Disease Control and Prevention. 1998. Preventing emerging infectious diseases: a strategy for the 21 st century overview of the updated CDC Plan.

Ceyssens PJ, R Lavigne. 2010. Introduction to bacteriophage biology and diversity. In: Sabour P, Griffiths M (eds). Bacteriophages in the control of food and waterborne pathogens. ASM Press. Washington, DC, USA, Pp 11-29.

Dabrowska K, K Switala-Jelen, A Opolski, B Weber-Dabrowska, A Gorski. 2005. Bacteriophage penetration in vertebrates. J Appl Microbiol 98, 7-13.

Filho R, J Higgins, S Higgins, G Gaona, A Wolfenden, G Tellez, G, B Hargis. 2007. Ability of bacteriophages isolated from different sources to reduce Salmonella enterica serovar Enteritidis in vitro and in vivo. Poultry Sci 86, 19041909.

Fiorentin L, ND Vieira, W Barioni. 2005. Oral treatment with bacteriophages reduces the concentration of Salmonella Enteritidis PT4 in caecal contents of broilers. Avian Pathol 34, 258-263.

Freitag T, RA Squires, J Schmid. 2008. Naturally occurring bacteriophages lyse a large proportion of canine and feline uropathogenic Escherichia coli isolates in vitro. Res Vet Sci 85, 1-7.

García P, B Martínez, JM Obeso, A Rodríguez. 2008. Bacteriophages and their application in food safety. Lett Appl Microbiol 47, 479-485.

Gill JJ, JC Pacan, ME Carson, KE Leslie, MW Griffiths, PM Sabour. 2006. Efficacy and pharmacokinetics of bacteriophage therapy in treatment of subclinical Staphylococcus aureus mastitis in lactating dairy cattle. Antimicrob Agents Chemother 50, 2912-2918.

Gorski A, B Weber-Dabrowska. 2004. The potential role of endogenous bacteriophages in controlling invading pathogens. Cell Mol Life Sci 62, 511-519.

Hagens S, MJ Loessner. 2007. Application of bacteriophages for detection and control of foodborne pathogens. Appl Microbiol Biotechnol 76, 513-519.

Hawkins C, D Harper, D Burch, E Anggard, J Soothill. 2010. Topical treatment of Pseudomonas aeruginosa otitis of dogs with a bacteriophage mixture: A before/after clinical trial. Vet Microbiol 146, 309-313.

Higgins S, JP Higgins, I Bielke, B Hargis. 2007. Selection and application of bacteriophages for treating Salmonella Enteritidis infections in poultry. Int Jour Poultry Sci 6, 163168.

Hudson JA, C Billington, G Carey-Smith, G Greening. 2005. Bacteriophages as biocontrol agents in food. J Food Prot 68, 426-437.

Huff WE, GR Huff, NC Rath, JM Balog, AM Donoghue. 2003. Bacteriophage treatment of a severe Escherichia coli respiratory infection in broiler chickens. Avian Dis 47, 13991405.

Joerger RD. 2003. Alternatives to antibiotics: bacteriocins, antimicrobial peptides and bacteriophages. Poultry Sci 82, 640-647.

Johnson RB, CL Gyles, WE Huff, S Ojha, GR Huff, NC Rath, AM Donoghue. 2008 Bacteriophages for prophylaxis and therapy in cattle, poultry and pigs. Anim Health Res Rev 9, 201-215.

Koo J, DL Marshall, A Depaola. 2001. Antacid increases survival of Vibrio vulnificus and Vibrio vulnificus phage in a gastrointestinal model antacid increases survival of Vibrio vulnificus and Vibrio vulnificus phage in a gastrointestinal model. Appl Environ Microbiol 67, 2895-2902.

Kutter E, A Sulakvelidze. 2005. Bacteriophages: biology and applications. CRC Press, Boca Raton, Fla, USA.

Labrie SJ, JE Samson, S Moineau. 2010. Bacteriophage resistance mechanisms. Nat Rev Microbiol 8, 317-327.

Lee N, DL Harris. 2001. Effect of bacteriophage treatment as a preharvest intervention strategy to reduce the rapid dissemination of Salmonella Typhimurium in pigs. Proc. AASV American Association of Swine Veterinarians, Perry, IA, USA, Pp 555-557.

Lee N, DL Harris. 2003. Compositions and methods for reducing the amount of Salmonella in livestock. US Patent 6, 656,463 , USA.

Letellier L, P Boulanger, L Plançon, P Jacquot, M Santamaria. 2004. Main features on tailed phage, host recognition and DNA uptake. Front in Biosc 9, 1228-1239.

Lim TH, MS Kim, DH Lee, HN Lee, JK Park, HN Youn, HJ Lee, SY Yang, YW Cho, JB Lee, SY Park, IS Choi, CS Song. 2012. Use of bacteriophages for biological control of Salmonella Enteritidis infection in chicken. Res Vet Sci 93, 1173-1178.

Loc-Carrillo C, ST Abedon. 2011. Pros and cons of phage therapy. Bacteriophage 1, 111-114.

Loc-Carrillo C, RJ Atterbury, A El-Shibiny, PL Connerton, E Dillon, A Scott, IF Connerton. 2005. Bacteriophage therapy to reduce Campylobacter jejuni colonization of broiler chickens. Appl Environ Microbiol 71, 6554-6563.

Lu TK, M Koeris. 2011. The next generation of bacteriophage therapy. Curr Opin Microbiol 14, 524-531.

Machado VS, MLS Bicalho, RV Pereira, LS Caixeta, JHJ Bittar, G Oikonomou, RO Gilbert, RC Bicalho. 2012. The effect of intrauterine administration of mannose or bacteriophage on uterine health and fertility of dairy cows with special focus on Escherichia coli and Arcanobacterium pyogenes. J Dairy Sci 95, 3100-3109.

Martínez-Borra J, S González, C López-Larrea. 2012. The origin of the bacterial immune response. Adv Exp Med Biol 738, 1-13.

Maura D, L Debarbieux. 2011. Bacteriophage as twenty-first century antibacterial tools for food and medicine. Appl Microbiol Biotechnol 90, 851-859.

Merril CR, B Biswas, R Carlton, NC Jensen, GJ Creed, S Zullo, S Adhya. 1996. Long-circulating bacteriophage as antibacterial agents. Proc Natl Acad Sci USA 93, 3188-3192.

Monk AB, CD Rees, P Barrow, S Hagens, DR Harper. 2010. Bacteriophage applications: where are we now? Letters Appl Microbiol 51, 363-369.

Nakai T. 2010. Application of bacteriophages for control of intectious diseases in aquaculture. In: Sabour PM, Griffiths MW (eds). Bacteriophage in the Control of Food-and Waterborne Pathogens. ASM Press, Washington DC, USA, Pp 257-272.

Nechaev S, K Severinov. 2008. The elusive object of desireinteractions of bacteriophages and their hosts. Curr Opin Microbiol 11, 186-193. 
Newell DG, M Koopmans, L Verhoef, E Duizer, A Aidara-Kane, H Sprong, M Opsteegh, M Langelaar, J Threfall, F Scheutz, J Van Der Giessen, H Kruse. 2010. Food-borne diseases - The challenges of 20 years ago still persist while new ones continue to emerge. Int J Food Microbiol 139, $3-15$.

Omnilytics Inc. 2007. Omnilytics announces USDA/FSIS allowance bacteriophage treatment E. coli $\mathrm{O} 157: \mathrm{H} 7$ on livestock. January 2. OmniLytics, Inc., Salt Lake City, UT, USA.

Payne RJ, VA Jansen. 2001. Understanding bacteriophage therapy as a density-dependent kinetic process. J Theor Biol 208, 37-48.

Pereira C, YJ Silva, AL Santos, A Cunka, NCM Gomes, A Almeida. 2011. Bacteriophages with potential for inactivation of fish pathogenic bacteria: survival, host specifity and effect on bacterial community structure. Mar Drugs 9, 2236-2255.

Raya RR, RA Oot, B Moore-Maley, S Wieland, TR Callaway, EM Kutter, AD Brabban. 2011. Naturally resident and exogenously applied T4-like and T5-like bacteriophages can reduce Escherichia coli O157:H7 levels in sheep guts. Bacteriophage 1, 15-24.

Rozema EA, TP Stephens, SJ Bach, EK Okine, RP Johnson, K Stanford, TA Mcallister. 2009 Oral and rectal administration of bacteriophages for control of Escherichia coli O157:H7 in feedlot cattle. J Food Protect 72, 241-250.

Santos TMA, EC Ledbetter, LS Caixeta, MLS Bicalho, RC Bicalho. 2011. Isolation and characterization of two bacteriophages with strong in vitro antimicrobial activity against Pseudomonas aeruginosa isolated from dogs with ocular infections. Am J Vet Res 72, 1079-1086.

Sashital DG, B Wiedenheft, JA Doudna. 2012. Mechanism of foreign DNA selection in a bacterial adaptive immune system. Mol Cell 46, 606-615.

Sheng H, HJ Knecht, IT Kudva, CJ Hovde. 2006. Application of bacteriophages to control Escherichia coli $\mathrm{O} 157: \mathrm{H} 7$ levels in ruminants. Appl Environ Microbiol 72, 53595366.

Sklar IB, RD Joerger. 2001. Attempts to utilize bacteriophage to combat Salmonella enterica serovar Enteritidis infection in chickens. J Food Saf 21, 15-30.

Skurnik M, E Strauch. 2006. Phage therapy: facts and fiction. $J$
Med Microbiol 296, 5-14.

Slanetz L, E Jawetz. 1941. Isolation and characteristics of bacteriophages for Staphylococci of bovine mastitis. $\mathrm{J} \mathrm{Bac}$ teriol 41, 447-455.

Smith HW, MB Huggins, KM Shaw. 1987. Factors influencing the survival and multiplication of bacteriophages in calves and in their environment. J Gen Microbiol 133, 1127 1135 .

Stern A, R Sorek. 2011. The phage-host arms race: shaping the evolution of microbes. Bioessays 33, 43-51.

Sulakvelidze A, Z Alavidze, J Morris. 2001. Bacteriophage therapy. Antimicrob Agents Chemother 45, 649-659.

Sulakvelidze A, E Kutter. 2005. Bacteriophage therapy in humans. In: Kutter A, Sulakvelidze A (eds). Bacteriophages: Biology and Applications. CRC Press, Boca Raton, USA, Pp 381-436.

Sulakvelidze P, A Barrow. 2005. Phage therapy in animals and agribusiness. In: Kutter A, Sulakvelidze A (eds). Bacteriophages: Biology and Applications. CRC Press, Boca Raton, USA, Pp 335-380.

Summers WC. 2001. Bacteriophage therapy. Annu Rev Microbiol 55, 437-451.

Tanji Y, T Shimada, H Fukudomi, K Miyanaga, Y Nakai, H Unno. 2005. Therapeutic Use of Phage Cocktail for Controlling Escherichia coli $\mathrm{O} 157: \mathrm{H} 7$ in Gastrointestinal Tract of Mice. J Biosci Bioeng 100, 280-287.

Toro H, SB Price, AS Mckee, FJ Hoerr, J Krehling, M Perdue, L Bauermeister. 2005. Use of bacteriophages in combination with competitive exclusion to reduce Salmonella from infected chickens. Avian Dis 49, 118-124.

Wagenaar JA, MAP Van Bergen, MA Mueller, TM Wassenaar, RM Carlton. 2005. Phage therapy reduces Campylobacter jejuni colonization in broilers. Vet Microbiol 109, 275283.

Wall SK, J Zhang, MH Rostagno, PD Ebner. 2010. Phage therapy to reduce preprocessing Salmonella infections in market-weight swine. Appl Environ Microb 76, 48-53.

WHO, World Health Organization. 2000. Overcoming antimicrobial resistance. World Health Organization (Report on Infectious Diseases), Geneva, Switzerland.

Xie H, X Zhuang, J Kong, G Ma, H Zhang. 2005. Bacteriophage Esc-A is an efficient therapy for Escherichia coli 3-1 caused diarrhea in chickens. J Gen Appl Micro 51, 159-163. 
